\title{
Reform towards Mutual Learning
}

Die Globalisierung untergräbt die Legitimation des klassischen nationalstaatlichen Steuerungsmodus. Dies hat auch Auswirkungen auf die Europäische Union. Ein demnächst erscheinendes Weißbuch der Europäischen Kommission wird sich mit notwendigen Reformen beschäftigen. Dabei geht es weniger um die bloße Beseitigung eines "Demokratiedefizits", als um eine Veränderung der traditionellen, von Technokraten dominierten Governance-Formen. An der Bewältigung eines Politikproblems müssen stärker Experten aus anderen Bereichen sowie die Bürger beteiligt werden, um wechselseitige Lernprozesse zu fördern. Dies wird auch den Politikprozess und die Rolle des Staates verändern.

$\mathrm{T}$ Von John Paterson here is disagreement about precisely what globalisation is. Some indeed are sceptical that it even exists as something distinct from developments that have been going on for centuries. But irrespective of how exactly one characterises contemporary conditions, some aspects are relatively clear. Among these is the increasingly problematic place of democracy in a context where its traditional foundations in the nation state appear to be under considerable pressure. Of course, the current role of the nation state is one of the key battlegrounds for opposing schools of political and economic thought. But whether one sees it as having little significance in the face of global flows of capital or as part of the continuing politico-legal framework within which trans-national economic actors must operate, it is nevertheless the case that the democratic legitimation processes that have characterised the modern nation state, especially since the $19^{\text {th }}$ century, appear increasingly inadequate.

To put it bluntly, the broad-brush renewal of government mandates in periodic elections may have been sufficient when democracy, especially with anything like a representative franchise, was itself a comparative innovation and when states deployed exclusive authority to deal with social problems that were by and large contained within their own territorial borders. In the vastly different conditions of the contemporary world, however, it is a question whether that minimal form of democracy is still enough to meet both the demands of citizens and the challenges posed by the sorts of problems now confronting government actors.
Regionalisation is identified by some as a symptom or characteristic of globalisation, and the European Union (EU), having had to grapple with issues of legitimacy beyond the nation state for half a century, is often cited as the paradigm case. The forthcoming White Paper of the European Commission on European Governance therefore promises to be a rich source of ideas for accountable government in contemporary conditions. The work of the European Commission's Forward Studies Unit over the past few years has fed into the process of preparing the White Paper. A collection of papers emerging from this work has recently been published and this short article gives a flavour of the findings (1).

\section{The Emerging Policy Environment}

For several years now, a popular complaint levelled at the EU is that it lacks democratic legitimacy. The institutions themselves have acknowledged what has come to be known as the democratic deficit. As a consequence, a great deal of attention has been focused on the extent to which the EU falls short of democratic arrangements in place at the national level and on how analogous arrangements could be implemented at the EU level. The European Parliament has accordingly been targeted as a likely candidate for reform. As the only elected institution, the theory runs, by enhancing its powers, perhaps in terms of scrutinising the work of the other institutions, perhaps even by granting it a veto, the democratic deficit can be reduced. As compelling as this approach is, it misunderstands the nature of the challenge now facing the EU. For a start, it ignores the fact that even at the level of the Member States, existing democratic arrangements are increasingly seen as in- adequate. If discontent and scepticism with the Union are to be meaningfully addressed, it will be necessary to produce a more adequately complex diagnosis of current problems.

First of all, it is necessary to take account of the fact that, whether one calls it globalisation or not, forces and processes transcending the boundaries of the EU seem clearly to be beyond the straightforward control of any of the institutions or levels of governance. Recent pressure on the European Central Bank from the International Monetary Fund in the face of the downturn in the US economy is an indication of the extent to which institutions, whose sphere of influence is nominally tied to given territorial boundaries delude themselves if they think that they can control in a strong sense what happens within those boundaries and are immune from what happens outside them. Global financial risk is perhaps uppermost in European minds at present, but a similar analysis can also be made of environmental, technological and health issues.

In all such cases, governance has traditionally been in the hands of experts, the supposed advantage being that as complexity increases technocrats can acquire and deploy the narrow and detailed knowledge needed to achieve control. A side effect of this approach, of course, is that such governance has been effectively removed from democratic scrutiny. Since it is based on science and is therefore inescapably rational, it does not require further legitimation. But as the number of crises and scares has mounted it has become increasingly clear that, for all its apparent rationality, this approach has not always produced the expected results. Nature has often proved intractable, throwing up unforeseen externalities. While problems such as these have also confronted government at the national level, there are a number of reasons why they are of particular significance to the EU.

Generally speaking, the European project has followed a trajectory from negative to positive integration. Whereas initially the concern was to remove barriers to the establishment of a common market and to guarantee the four freedoms (of commodities, services, capital and labour), it became progressively apparent that the completion of a single market would require active intervention in more and more policy areas which, at first sight, may have seemed remote from the question of barriers to trade but which, if left untouched, would have allowed Member States to enjoy unfair competitive advantages. 
Neuerscheinung:

UnternehmensGrün Band 7

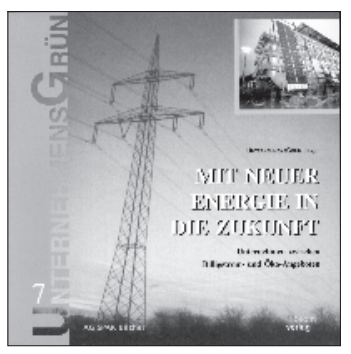

\section{Mit neuer Energie in die Zukunft}

Unternehmen zwischen Billigstrom und Öko-Angeboten

Seit einiger Zeit beginnt die Öffnung des Energiemarktes zu greifen: Große Energieversorgungsunternehmen buhlen mit Strom zu Tiefstpreisen um die KundInnen. Daneben präsentieren sich zahlreiche Newcomer mit unterschiedlichen Ökostrom-Angeboten auf dem Markt. Wie können die Unternehmen als Verbraucher darauf reagieren? Band 7 der Reihe UnternehmensGrün informiert über die vielfältigen Chancen einer ökologischen und regenerativen Energiezukunft. Fachleute aus Wissenschaft, Wirtschaft, Politik und Finanzwelt berichten über die neuesten Entwicklungen auf dem Energiemarkt und wie jeder davon profitieren kann.

Unternehmensgrün, Verband zur Förderung umweltgerechten Wirtschaftens (Hrsg.), Band 7, 168 Seiten, 25 DM, ökom Verlag, ISBN 3-925244-66-3.

Reihe UnternehmensGrün ist DIE Basislektüre für das Unternehmen der Zukunft: Band 1

"Augen zu und durch?

Was kommt nach der Krise?" - Über den konstruktiven Umgang mit der Rezession

\section{Band 2}

Erhalt durch Veränderung.

Perspektiven einer ökologischen und sozialen Umsteuerung

Band 3

Konkurrenten oder Partner. Ökobilanz undf Öko-Audit im Verlgeich

\section{Band 4}

Von der Vision zur Praxis.

Nachhaltiges Wirtschaften als Perspektive für Unternehmen

Band 5

Märkte ohne Grenzen. Unternehmen im Spannungsfeld zwischen nachhaltigen Wirtschaften und globalen Wettbewerb

Band 6

Arbeit - Strategien der Existenzsicherung

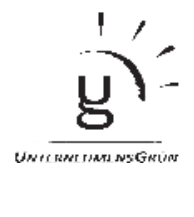

This is a significant shift, but it is a question whether the structure of the European policy process has adapted sufficiently to reflect it. At the outset, there were two complementary forces that encouraged an essentially vertical structure. On the one hand, Member States recognised the advantages in sharing sovereignty in areas where there were already significant interdependencies. On the other, the political elite driving the project recognised that it was important to achieve an institutional structure that provided strong, centralised control of these policy areas. For as long as the community was concerned with issues of negative integration, this vertical and centralised structure was not subject to serious sustained challenge. Over time, however, the Community's involvement with positive integration developed exponentially - especially with the Single European Act in 1986. This has exposed weaknesses in centralised arrangements and built up decentralising pressures.

Problems have also arisen because of the functional segmentation of the European policy process. This is manifest in the division of administrative actors into discrete directorates general or ministries or departments, each responsible for clearly defined policy areas. While this approach has often been successful in coping with the emergence of new problems and in managing complexity, it has more recently begun to show signs of strain under the sheer weight of the responsibilities now lying with public actors. Focusing on a given aspect of the policy environment can serve to reduce complexity, but it can also serve to mask it by hiding the interdependencies that may exist between policy areas - either in the form of negative externalities or of synergistic opportunities.

\section{Key Dimensions of Governance Reform}

Understanding the emerging policy environment in this more adequately complex way indicates why it is necessary to consider governance reform in EU in terms other than those of the traditional debate on the democratic deficit. It is necessary not to address the simple distance between Europe and the citizen, but to reappraise the very nature of that relationship. The White Paper will be an opportunity to put this observation into practice when citizens and institutional actors will be able to enter into a dialogue regarding the future of policy formation and implementation in the EU. It is possible, however, on the basis of the diagnosis briefly sketched above to indicate some of the key dimensions that must be addressed if governance arrangements are to be able to cope with the nature of the emerging policy environment.

There is a need first of all to consider how to overcome limited understandings of problems. This will involve a variety of factors including: extending consultation beyond the well-organised and often very narrow interests who currently dominate the policy process; and considering the division that can exist between expert and lay knowledge, and indeed between different types of expert knowledge.

Related to this is the need to consider how to guarantee wider participation in the policy process. This is not simply a question of improving the participation of citizens, but also of improving the involvement of experts from other disciplines and other policy areas where this is perceived to be necessary.

- Insofar, however, as wider participation does indeed involve citizens, it will be necessary to take account of inequalities in both material and cognitive resources.

- A similarly open and inclusive approach will be required with respect to the ongoing evaluation and the revision of policies. Evaluation is at present too often a closed and arcane process producing results that are not fed back into the process to improve existing policies.

If there is an overarching theme to this brief account of the new modes of governance implied by the diagnosis of the emerging policy environment, it is that reformed arrangements must seek to encourage mutual learning.

\section{Enhancing Mutual Learning}

We can perhaps get a better impression of why the encouragement of mutual learning unites all of the dimensions if we move on to consider the nature and status of knowledge. Whereas it is increasingly common to find scientific rationality profoundly questioned and decentred - especially in the post-modern literature - a closer examination reveals the extent to which it is more modest than its critics often allow and is aware of its own limitations. Scientific rationality after all produces knowledge and not certainty. This knowledge is not absolute but rather provisional and inherently and necessarily subject to ongoing testing, revision and even replacement.

As a consequence, the policy process needs to be able to accommodate not only the possibility that 
expert opinion may be wrong or perhaps only relatively right, but also the probability that different expert disciplines deploying the same scientific rationality will conceptualise issues in different ways. This does not mean that expert knowledge is devalued. To be clear, scientific rationality remains the best means we have of generating knowledge. But it does mean that it is no longer possible to justify the removal of policy issues from the democratic arena on the basis that they are the preserve of experts. It also means that experts and citizens can, indeed must, learn from each other.

Opportunities for mutual learning in a reformed policy process would, therefore, need to encourage an acceptance of the necessarily incomplete and provisional nature of any perspective brought to a given interaction and seek to facilitate a mutual critique of those perspectives by the different stakeholders whether expert or lay. Different stakeholders would be required to demonstrate the coherence of their constructions, not only in terms of their initial positions but also in terms of the positions of others emerging as part of the ongoing process of mutual learning.

\section{- Implications for the Policy Process}

Understanding the policy process as a process of mutual learning has implications for effectiveness and for legitimacy. Effectiveness is enhanced insofar as a more adequate understanding of the problems at hand emerges. This does not mean that a given perspective cannot simply be wrong. It means only that there is no pre-judgement in this regard, that such an assessment can only be made on the basis of reasoned discussion. Overcoming the limited understandings of existing approaches thus involves informing expert opinion with lay judgement to the extent that that is appropriate and equally assisting other perspectives to understand the reasoning behind expert findings and their impact. It also means, of course, in the context of fragmented knowledge, assisting mutual learning between different expert understandings of a given issue.

Effectiveness can also be enhanced insofar as problem- and objective-setting, choice and implementation of means, and evaluation and revision of policy do not focus solely on a given policy domain. The emphasis must be on ensuring that these different stages of the policy process in a given domain are aware of the impact of decisions taken on other policy areas. It is already the case that the more inclusive approach envisaged above - encompassing broader expert and lay input - will heighten the likelihood that transboundary or cross-cutting problems will be identified and incorporated into decision-making. But this cannot be left to chance. Rather, new modes of governance need to address the question of policy coherence from the outset and build in procedures for ensuring that negative externalities and synergistic opportunities are identified and acted upon.

Finally, this understanding of the emerging policy environment has implications for the way in which public actors understand their precise role. In particular, the control aims of governmental action are shifted away from the top-down definition of ends and means and towards the establishment of and support for inclusive, participatory procedures oriented towards mutual learning. There is no question of public actors no longer being concerned with the attainment of objectives. It is simply that these must come to be understood as collectively-generated and inherently mutable goals which are expressions of a contextualised rather than of a general will which in any case is increasingly understood to be more symbolic than real. Nor is there any dilution of responsibility as regards public actors. As guardians of a policy process understood as being enhanced by opportunities for mutual learning, the location and the weight of responsibility are as clear and as onerous as ever.

The debate on governance in the context of globalisation is essentially only beginning. The White Paper on European Governance has the potential to make a significant contribution. It remains to be seen, however, whether that potential is realised.

\section{Reference}

(1) De Schutter, Olivier/ Lebessis, Notis/ Paterson, John (eds.): Governance in the European Union. Office for Official Publications of the European Communities, Luxembourg 2001. Also published in French.

\section{Der Autor}

Dr. John Paterson ist Juradozent an der University of Westminster.

Kontakt: School of Law, University of Westminster, 4 Little Titchfield Street, London, WIW 7UW, Großbritannien. Tel. 0044-20-7911-5000 Ext. 2514; Fax -5821, E-mail: J.Paterson@wmin.ac.uk.
Neu im ökom verlag

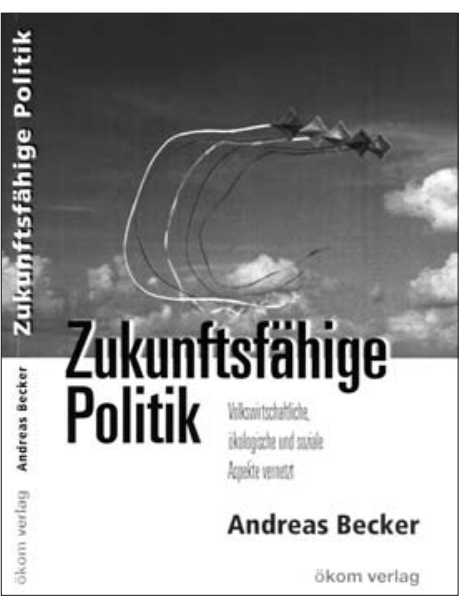

Die Gesellschaft lebt über ihre Verhältnisse und auf Kosten der Zukunft: ökologisch, ökonomisch, sozial - mit globalen Auswirkungen.

Das Konzept der Zukunftsfähigkeit will das Handeln zu Lasten der Zukunft stoppen. Viele bisherige Ansätze jedoch verengen das Thema auf die ökologische Perspektive. Dieses Buch dagegen erweitert es um volkswirtschaftliche, soziale und globale Gesichtspunkte zu einer Gesamtsicht, die das Verhalten komplexer Systeme einbezieht. Das Ergebnis ist ein ganzheitlicher Ansatz mit Grundsätzen und einer Vision für Zukunftsfähigkeit.

Das übersichtlich gegliederte Buch richtet sich an politisch und gesellschaftlich, ökonomisch und ökologisch interessierte Bürgerlnnen ebenso wie PolitikerInnen, Umweltgruppen, Wirtschaftsund Sozialverbände.

\section{www.oekom.de}

ökom Verlag, Waltherstr. 29,

D - 80337 München,

Fon $++49 /(0) 89 / 51639892$,

Fax ++49/(0)89/544 184-99,

E-Mail kontakt@oekom.de

www.oekom.de 
(c) 20I0 Authors; licensee IÖW and oekom verlag. This is an article distributed under the terms of the Creative Commons Attribution Non-Commercial No Derivates License (http://creativecommons.org/licenses/by-nc-nd/3.o/), which permits unrestricted use, distribution, and reproduction in any medium, provided the original work is properly cited. 